\title{
MATHEMATICS EFFICACY AMONG STUDENTS WITH DYSCALCULIA IN PUBLIC HIGH SCHOOLS IN KANDARA SUB-COUNTY, MURANGA COUNTY, KENYA
}

\author{
Nicholas Matunda Mariera ${ }^{1 \mathrm{i}}$, \\ Margaret Murugami ${ }^{2}$, \\ Jessina Muthee ${ }^{3}$ \\ 1P.O. Box 1538-01000, \\ Thika, Kenya \\ ${ }^{2}$ Dr., Department of Early Childhood and \\ Special Needs Education, \\ Kenyatta University, \\ Nairobi, Kenya \\ ${ }^{3}$ Dr., Department of Special Needs Education, \\ Kenyatta University, \\ P.O. Box 43844-00100, \\ Nairobi, Kenya
}

\begin{abstract}
:
The thrust of the study was to determine levels of mathematic efficacy among students with dyscalculia in public secondary in Kandara sub-county in Muranga County guided by Expectancy Theory (ET) of motivation developed in 1964 by Victor Vroom. The study adopted a descriptive research design. The population for study was 54 Public secondary schools in Kandara Sub-County, out of the 54 targeted schools 7 public secondary schools were sampled for the study. The target respondents were 7 principals, 7 teachers of mathematics, 1 from each school and 125 students were sampled for dyscalculia screening. Research instruments included: questionnaire for mathematics students with dyscalculia, dyscalculia screening instrument, mathematics self -efficacy scale and documentary analysis. Pilot study was conducted in Gaichanjiru Mixed and Kenyoho Secondary schools in Kandara Sub-County, Murang'a County. The validity of research instruments which were used for this study were first tried in a pilot study which helped in clarification of ambiguities prevalent before data collection while the reliability of the research instruments in this study was determined using Pearson product moment correlation coefficient formula. The study used stratified random sampling and purposive sampling to select the schools, teachers and students with dyscalculia respectively. Data for the main study was collected and analyzed both quantitatively and qualitatively (Mixed method research). Quantitative data was analyzed using the Statistical Package for Social Sciences (SPSS 26.0), while qualitative analysis was done by
\end{abstract}

${ }^{i}$ Correspondence: email matundanicholas@gmail.com 
organizing variables into themes. The study reveals that learners without dyscalculia exhibited high self-efficacy in mathematics while those with dyscalculia displayed low self-efficacy in mathematics. The researcher recommends that Students' mathematics efficacy should be improved by inviting mentors or people who have succeeded in mathematical field to help boost their morale in the subject.

Keywords: dyscalculia, public secondary school and mathematics self-efficacy

\section{Introduction}

Dyscalculia is defined as difficulty in acquiring basic arithmetic skills that is not explained by low intelligence or inadequate schooling (Kaufmann L. and Von Aster M., 2012). Public secondary schools: "public school" means a school maintained or assisted out of public funds (Education act, 2012). Mathematics self-efficacy is a situational evaluation of individual's trust/capacity to effectively perform or finish a specific numerical assignment or issue (Jason S. Briley, 2012).

Students with learning difficulties go through more than one difficulty throughout their academic career. Specifically, they face problems in motivation attribution, selfregard and full of feeling reactions and also challenges in key information and selfobserving that can contrarily affect scholastics (Borkowski, 1992). Borkowski, Catt, Rellinger \& Pressley (1990) discusses an integrated model of achievement, focusing on two distinct dimensions: meta-cognition and affective factors. Metacognition encompasses self- knowledge of learning strategies and the ability to use this knowledge in an efficient and effective manner. The affective component focuses on feelings of selfefficacy with factors of motivation, locus of control and personal attribution (Borkowski et al., 1990).

Self-efficacy is the evaluation of individual abilities to sort out and influence strategies to accomplish objectives. Presented by Bandura (1977), in the field of psychology and education, the idea of self-efficacy has been investigated widely. It impacts human working specifically and in a roundabout way as a multi-dimensional develop, through its consequences for different determinants (Bandura, 1997), for example, feeling, attribution, self-regulation and inspiration. In the field of research, and specifically in its part in academics has demonstrated positive connection with execution accomplishment (Bandura, 1986; Bempechat and Drago-Severson, 2009; Covington, 2000; Pajares, 1996; Patrick, Hicks and Ryan, 1997; Schunk, 1995; Zimmerman, Bandura and Martinez-Pons, 1992).

Self-efficacy in Mathematics among students with dyscalculia is an interesting area to explore because it would reveal the motivational needs that should put in place to encourage students believe in their capabilities so as to counter difficulties while performing tasks related to Mathematics. Although boys generally perform better than girls in Mathematics in Kenya, overall performance of all the students in Mathematics is quite low. The national mean grade in mathematics is below 20 per cent (KNEC, 2006). 
In Kandara sub-county the mean score for mathematics has been mean grade of a D for the last four years. The mean score was 2.926, 3.3660, 3.430 and 3.3211 from the year 2011 to 2014 respectively according to the Ministry of Education Science and Technology, Kandara Sub-County (2015). Walsh (2008), suggested that "affective variables including mathematics anxiety, beliefs about mathematics and mathematics self-efficacy contribute to success in mathematics. Mathematics anxiety is an important educational issue and is related to mathematics achievement". Consequently, this study sought to establish mathematics efficacy among learners with dyscalculia in public secondary in Kandara sub-county, Muranga County, Kenya.

\section{Objectives of Study}

To establish the level of mathematics efficacy among learners with dyscalculia in public secondary schools in Kandara sub-county, Muranga County, Kenya

\section{Materials and Methods}

This study adopted descriptive survey design to enable the researcher to obtain pertinent and precise information concerning learners with dyscalculia mathematics efficacy in public secondary schools in Kandara sub-county and draw valid conclusions for the facts that the researcher discovered. The researcher adopted this design because it helps the researcher to determine and report the way things are and also attempts to describe possible behaviors, values, attitudes and characteristics according to Kombo \& Tromp (2006). Data was collected by administration of Dyscalculia screening instrument and documentary analysis, the information gathered was used to establish the learners with dyscalculia mathematics efficacy in public secondary schools in Kandara sub-county. The instruments that were used for this study included the following: Dyscalculia screening instrument and a questionnaire for teachers and students.

Data collected was checked for completeness. It was then edited, coded, tabulated and entered in the computer for final analysis. Dyscalculia screening test, was thoroughly inspected for accuracy. Data from the research instruments was analyzed both quantitatively and qualitatively. Analysis was done using the Statistical Package for Social Sciences (SPSS). Descriptive statistics was organized in a meaningful way for presentation, interpretation and discussion. The analyzed data was presented using percentages and frequency in tables and figures.

\section{Results and Discussion}

Students from Kandara sub-county secondary schools who participated in this study were in the age range between 15- 21 years. These students were both male and female with a slight difference in number at 57 and 68 respectively. The students attended either girls only, boys only or mixed secondary schools. All the sampled students were included 
in the study because they were found to experience difficulties in mathematics a maths test was administered to the students in order to identify those with dyscalculia in public secondary schools in Kandara sub-county. The Frequencies and percentages under descriptive statistics were applied to present the quantitative data. The scale was subjected to all the students in the study in order to compare the self-efficacy ratings between those with dyscalculia against those without dyscalculia.

\subsection{Students Ratings on the Level of Self-Efficacy for Mathematics}

In table 4.1, data gathered from students on the level of self-efficacy for mathematics are presented in frequencies and percentages.

Table 4.1: Students Ratings on the level of Self-Efficacy for Mathematics Performance

\begin{tabular}{|l|c|c|c|c|c|c|c|c|c|c|}
\hline & \multicolumn{2}{|c|}{$\begin{array}{c}\text { Strongly } \\
\text { Agree }\end{array}$} & \multicolumn{2}{|c|}{ Agree } & \multicolumn{2}{c|}{$\begin{array}{c}\text { Neither Agree } \\
\text { nor Disagree }\end{array}$} & \multicolumn{2}{c|}{ Disagree } & \multicolumn{2}{c|}{$\begin{array}{c}\text { Strongly } \\
\text { Disagree }\end{array}$} \\
\hline & $\mathrm{F}$ & $\%$ & $\mathrm{~F}$ & $\%$ & $\mathrm{~F}$ & $\%$ & $\mathrm{~F}$ & $\%$ & $\mathrm{~F}$ & $\%$ \\
\hline $\begin{array}{l}\text { I always try my best in } \\
\text { maths class }\end{array}$ & 42 & 33.6 & 48 & 38.4 & 26 & 20.8 & 3 & 5.6 & 6 & 4.8 \\
\hline I enjoy taking maths & 54 & 43.2 & 32 & 25.6 & 32 & 25.6 & 8 & 6.4 & 0 & 0.0 \\
\hline $\begin{array}{l}\text { I would like to learn more } \\
\text { about maths in college }\end{array}$ & 31 & 24.8 & 63 & 50.4 & 23 & 18.4 & 0 & 0.0 & 8 & 6.4 \\
\hline $\begin{array}{l}\text { My teacher thinks i do not } \\
\text { understand maths very well }\end{array}$ & 8 & 6.4 & 0 & 0.0 & 25 & 20.0 & 52 & 41.6 & 34 & 27.2 \\
\hline I am not good at maths & 4 & 3.2 & 4 & 3.2 & 21 & 16.8 & 21 & 16.8 & 75 & 60.0 \\
\hline $\begin{array}{l}\text { I believe that what i learn in } \\
\text { maths class is useful in the } \\
\text { real world }\end{array}$ & 72 & 57.6 & 34 & 27.2 & 11 & 8.8 & 0 & 0.0 & 8 & 6.4 \\
\hline $\begin{array}{l}\text { I get good grades in } \\
\text { mathematics }\end{array}$ & 63 & 50.4 & 20 & 16.0 & 34 & 27.2 & 0 & 0.0 & 8 & 6.4 \\
\hline $\begin{array}{l}\text { I am good at solving maths } \\
\text { problems }\end{array}$ & 49 & 39.2 & 20 & 16.0 & 42 & 33.6 & 2 & 1.6 & 6 & 6.4 \\
\hline $\begin{array}{l}\text { I do not like going to maths } \\
\text { class }\end{array}$ & 3 & 5.6 & 5 & 4.0 & 18 & 14.4 & 30 & 24.0 & 69 & 55.2 \\
\hline $\begin{array}{l}\text { I usually give up when } \\
\text { solving a maths problem }\end{array}$ & 8 & 6.4 & 0 & 0.0 & 25 & 20.0 & 60 & 48.0 & 32 & 25.6 \\
\hline $\begin{array}{l}\text { I feel confused during maths } \\
\text { class }\end{array}$ & 0 & 0.0 & 8 & 6.4 & 18 & 14.4 & 19 & 15.2 & 80 & 64.0 \\
\hline $\begin{array}{l}\text { When I am older, I want a } \\
\text { job that does not use maths }\end{array}$ & 33 & 26.4 & 17 & 13.6 & 14 & 11.2 & 23 & 18.4 & 38 & 30.4 \\
\hline $\begin{array}{l}\text { It is easy for me to pay } \\
\text { attention in mats class }\end{array}$ & 76 & 60.8 & 31 & 24.8 & 12 & 9.6 & 8 & 6.4 & 0 & 0.0 \\
\hline
\end{tabular}

Majority of the respondents exhibited high self-efficacy in mathematics in according to table 4.1. On the scale of 1 (lowest self-efficacy to 5 (highest self-efficacy). Most students score was ranging (strongly agreed-agreed) for 7 positive questions items similarly on negative questions, majority of their responses in the 6 questions items ranged between (strongly disagree and disagree). 
Table 4.1's findings show that $38.4 \%$ of the students agreed that they always try their best in maths class, $43.2 \%$ strongly agreed that they enjoyed taking maths, $50.4 \%$ agreed that they would like to learn more about maths in college, 57.6\% strongly agreed that what they learn in maths class is useful in real world, 50.4\% strongly agreed that they got good grades in mathematics while $39.2 \%$ strongly agreed that they are good at solving maths problems. Finally, $60.8 \%$ strongly agreed that it is easy for them to pay attention in maths class. The above responses were on positive questions on self-efficacy in mathematics.

On negative questions; $41.6 \%$ strongly disagreed that their teachers thought they do not understand maths very well, $60 \%$ strongly disagreed that they are not good at maths, $55.2 \%$ strongly disagreed that they do not like going to a maths class, $48.0 \%$ of the students disagreed that they usually give up when solving a maths problem, $64.0 \%$ strongly disagreed that they feel confused during a maths lesson, finally when asked whether they want not to do a job that will use maths, $30.4 \%$ of them strongly disagreed. From the above findings, Learners without dyscalculia exhibited high self-efficacy in mathematics while those with dyscalculia displayed low self-efficacy in mathematics.

In a rejoinder, Liu and Koirala (2009) carried out a correlation analysis and a survey linear regression analysis study in sophomores across the United States among 11726 high school students in 752 public and private schools. Just like the present study, their findings demonstrated that mathematics achievement and mathematics self-efficacy were positively related. Students recording high mathematics self-efficacy were positively correlated with high achievement in mathematics.

\subsection{Learners' Mathematics Performance in Various Areas}

In this section, learners were given a maths test to identify those with dyscalculia.

Table 4.2: Areas of Mathematics Difficulties and Their Frequency

\begin{tabular}{|l|c|c|}
\hline & F & \% \\
\hline Abstract thinking & 15 & 12.0 \\
\hline Mastery of maths concept & 40 & 32.0 \\
\hline Language difficulties & 20 & 16.0 \\
\hline Difficulties in time and direction & 15 & 12.0 \\
\hline Arithmetic weakness & 30 & 24.0 \\
\hline Visual-spatial aspects of maths & 5 & 4.0 \\
\hline Total & $\mathbf{1 2 5}$ & $\mathbf{1 0 0 . 0}$ \\
\hline
\end{tabular}

Table 4.2 above reports a majority of students $32 \%$ have difficulties with mastery of maths concept, $12 \%$ had difficulties in time and direction, $16 \%$ had difficulties in language of maths, $12 \%$ had difficulties with abstract thinking, $24 \%$ had arithmetic weakness while $4 \%$ had difficulties in visual-spatial aspect of maths. Therefore, students in the study area had difficulties in various areas of mathematics in common with the main common area being mastery of maths concepts followed by arithmetic difficulties. Other authors across the globe have also supported the results. For instance, studies have shown that there are 
diverse types of challenges that students with MD experience Fuchs, Prentice, and Fuchs (2002) and Jordan, Hinich, Dick and Kaplan (2001). The implication of these difficulties implies that maths failure is common among the indicated skills and therefore, students require diverse classroom intervention to understand some of the maths concepts.

\subsection{Students' maths test score vs mathematics self-efficacy score}

Students were asked to indicate the mathematics skills they felt they were good at (Table 4.26)

Table 4.3: Students' maths test scores vs Mathematics self-efficacy score

\begin{tabular}{|l|c|c|c|}
\hline Maths test Score (\%) & Frequency & MSE Score range & Percentage \\
\hline 0 & 2 & $13-20$ & 1.6 \\
\hline 10 & 1 & $21-24$ & 0.8 \\
\hline 45 & 6 & $25-30$ & 4.8 \\
\hline 50 & 20 & $39-42$ & 16.0 \\
\hline 55 & 48 & $43-45$ & 38.4 \\
\hline 60 & 10 & $46-49$ & 8.0 \\
\hline 65 & 21 & $50-52$ & 16.8 \\
\hline 70 & 3 & $53-55$ & 2.4 \\
\hline 75 & 13 & $56-60$ & 10.4 \\
\hline 80 & 1 & 62 & 0.86 \\
\hline
\end{tabular}

Results presented in the above table 4.26 reveal that a majority of $38.4 \%$ of the students scored 55\% and their MSE score was ranging 42-45, 16.8\% scored 65 with MSE score of ranging 50-52,16\% scored 50\% and their MSE score was ranging 39-42,10.4\% scored 75\% and their MSE score was ranging 53-55,8\% scored 60\% and their MSE score was ranging $56-49,4.8 \%$ scored $45 \%$ and their MSE score was ranging 25-30,2.4\% scored $70 \%$ and their MSE score was ranging 53-55,1.6\% scored 0 and their MSE was ranging 13-20,0.8\% scored $10 \%$ and their MSE was 23 and finally $0.8 \%$ scored $80 \%$ and their MSE was ranging was 62. Given the results, the researcher opines that students with low MSE scored marks ranging $0 \%-45 \%$ while those students with high MSE scored marks ranging $50 \%-80 \%$, therefore, $92.8 \%$ of students had MSE score levels high ranging 39-62 while 7.2\% of students were found to have low levels of MSE score ranging 13-30 as findings in table 4.26 established.

\subsection{Chi-Square Test on the Relationship between Mathematics Self-Efficacy and Mathematics Performance}

Table 4.4: Chi-Square Test on the Relationship between Mathematics Self-Efficacy and Mathematics Performance

\begin{tabular}{|l|c|c|c|}
\hline & Value & df & Asymp. Sig. (2-sided) \\
\hline Pearson Chi-Square & $500.000(\mathrm{a})$ & 64 & .000 \\
\hline Likelihood Ratio & 344.450 & 64 & .000 \\
\hline Linear-by-Linear Association & .068 & 1 & .794 \\
\hline N of Valid Cases & 125 & & \\
\hline
\end{tabular}


The chi-square test results on the relationship between mathematics self-efficacy and mathematics performance revealed that there exists a significant relationship between learners' mathematics self-efficacy and their mathematics performance. This is because the $p$-value $p=0.000$ is lower than $p=0.05$ hence the null hypothesis H04: "There is no significant relationship between learners' mathematics self-efficacy and mathematics performance" is rejected by this study. This is because the study has revealed that the $\mathrm{df}=64$, there exists a significant relationship between the studied variables

\section{Recommendations}

Students' mathematics efficacy should be improved by inviting mentors or people who have succeeded in mathematical field to help boost their morale in the subject.

\section{Conclusion}

The purpose of the study was to establish the level of mathematics self-efficacy among learners with dyscalculia in public secondary schools in Muranga, Kenya. The study was conducted using descriptive survey while data was collected using questionnaires and interviews.

The findings from the study reveals that learners without dyscalculia exhibited high self-efficacy in mathematics while those with dyscalculia displayed low self-efficacy in mathematics.

\section{Conflict of interest statement}

On behalf of all the co-authors I declare that authors have no conflict of interest with the manuscript.

\section{About the Authors}

Nicholas Matunda Mariera is currently enrolled for a Master's Degree in Special Needs Education at Kenyatta University. He holds a B.Ed. art in (Mathematics and Economics) from Masinde Muliro University of Science and Technology. He has worked as a teacher in a special unity at pre-school and a secondary school teacher for the last 14 years. He is currently working as a teacher in Kiranga Boys High School.

Dr. Murugami Margaret is a senior lecturer in the department of Early Childhood and Special Needs Education in Kenyatta University with a specialization in area of visual impairment. She has a doctoral degree from University of South Africa in inclusive education. Margaret has taught courses on inclusive Education at undergraduate and postgraduate levels. She has substantial knowledge on disability-related issues including the topic of this study. She has research interests in areas of special needs education, inclusive education, identity and disability, identity well-being and self-concept among learners with special needs. 
Dr. Jessina Jessica Muthee is a senior lecturer in Kenyatta university. She is a specialist in the area of learning disability and psycho-educational assessment. Her area of research interest includes, dyscalculia, dyslexia, dysgraphia, dysphasia, attention deficit hyperactive disorder, cognitive psychology, psychometry and abnormal psychology.

\section{References}

Bandura, A. (1977). Self-efficacy: Toward a unifying theory of behavioral change. Psychological Review. Retrieved from http://des.emory.edu/mfp /Pajares Schunk2001.html

Bandura, A. (1986). Social foundations of thought and action: A Social Cognitive Theory. Englewood cliffs. Prentice-Hall.

Borkowski, J. G. (1992). Metacognitive theory: A framework for teaching literacy, writing and math skills. Journal of Learning Disabilities, 25, 253 257.

Borkowski, J., Catt, G. Rellinger M., \& Pressley, M. (1990). Self-regulated cognition: Interdependence of metacognition, attributions, and self-esteem. In B. Jones \& L. Idol (Eds.) Dimensions of thinking and cognitive instruction (pp. 53 92 ). Hillsdale, NJ: Lawrence Erlbaum Associates.

Drago-severson, E. (2009). Leading adult learning: support adult development in our schools. Thousand oaks, CA: Corwin/Sage Press

Kenya National Examination Council (2006). The year 2006 KCSE Examination Performance Report. Nairobi. KNEC

Kaufmann, L., and von Aster, M. (2012). The diagnosis and management of dyscalculia. Dtsch. Arztebl. Int. 109, 767-778.

Kinyua, J., N. (2007). Promoting Parent-Teacher Collaboration in providing Education for Students with LD in primary schools in Kasarani Division, Nairobi, Kenya. Unpublished Master's Thesis Kenyatta University.

Kombo, D. K., \& Tromp, D. L. A. (2006). Proposal and thesis writing; an introduction: Pauline publications Africa.

Walsh, K. A. (2008). The relationship among mathematics anxiety, beliefs about mathematics, mathematics self-efficacy, and mathematics performance in associate degree nursing students. Nursing Education Perspectives, 29 (4), 226-229. 
Nicholas Matunda Mariera, Margaret Murugami, Jessina Muthee

MATHEMATICS EFFICACY AMONG STUDENTS WITH DYSCALCULIA

IN PUBLIC HIGH SCHOOLS IN KANDARA SUB-COUNTY, MURANGA COUNTY, KENYA

Creative Commons licensing terms

Author(s) will retain the copyright of their published articles agreeing that a Creative Commons Attribution 4.0 International License (CC BY 4.0) terms will be applied to their work. Under the terms of this license, no permission is required from the author(s) or publisher for members of the community to copy, distribute, transmit or adapt the article content, providing a proper, prominent and unambiguous attribution to the authors in a manner that makes clear that the materials are being reused under permission of a Creative Commons License. Views, opinions and conclusions expressed in this research article are views, opinions and conclusions of the author(s). Open Access Publishing Group and European Journal of Education Studies shall not be responsible or answerable for any loss, damage or liability caused in relation to/arising out of conflicts of interest, copyright violations and inappropriate or inaccurate use of any kind content related or integrated into the research work. All the published works are meeting the Open Access Publishing requirements and can be freely accessed, shared, modified, distributed and used in educational, commercial and non-commercial purposes under a Creative Commons Attribution 4.0 International License (CC BY 4.0). 